\title{
MENINGKATKAN KEMAMPUAN MEMBACA PERMULAAN MELALUI MEDIA PAPAN FLANEL DI KELOMPOK B TK NEGERI HARAPAN KITA ALEBO KABUPATEN KONAWE SELATAN
}

\author{
Marfiani ${ }^{1)}$, Ahid Hidayat ${ }^{2)}$ \\ ${ }^{1}$ Alumni Jurusan PG-PAUD, Universitas Halu Oleo. Jln. H.E.A Mokodompit, Kendari 93232, \\ Indonesia. \\ ${ }^{2}$ Dosen Jurusan PG-PAUD, Universitas Halu Oleo. Jln. H.E.A Mokodompit, Kendari 93232, \\ Indonesia.
}

E-mail/Telp: marfiani@gmail.com/082348237366

\begin{abstract}
Abstrak
Penelitian ini bertujuan untuk meningkatkan kemampuan membaca permulaan melalui media papan flanel di kelompok B TK Negeri Harapan Kita Alebo Kabupaten Konawe Selatan. Subjek dalam penelitian ini adalah guru dan anak didik yang berjumlah 16 orang. Jenis penelitian ini adalah penelitian tindakan kelas yang dilaksanakan dalam dua siklus. Pengumpulan data dalam penelitian ini menggunakan metode observasi, wawancara dan dokumentasi. Berdasarkan analisis data hasil observasi aktivitas mengajar guru pada siklus I diperoleh persentase ketercapaian sebesar 73,3\%, aktivitas belajar anak didik diperoleh persentase ketercapaian sebesar $69,28 \%$, sedangkan hasil belajar anak berupa peningkatan kemampuan membaca permulaan melalui media papan flanel sebelum dilakukan tindakan sebesar 37,5\% anak memperoleh nilai BSB dan BSH kemudian meningkat pada siklus I sebesar $62,5 \%$. Pada siklus II, persentase ketercapaian aktivitas mengajar guru mengalami peningkatan menjadi 93,33\%, persentase ketercapaian aktivitas belajar anak didik juga mengalami peningkatan menjadi $92.37 \%$ dan hasil belajar anak berupa peningkatan kemampuan membaca permulaan melalui media papan flanel meningkat sebesar 87,5\%.
\end{abstract}

Kata kunci: Kemampuan Membaca Permulaan, Media Papan Flanel, Anak

\section{IMPROVING EARLY READING ABILITY BY USING FLANNEL BOARD MEDIA AT GRUP B TK HARAPAN KITA ALEBO, KONAWE SELATAN}

\begin{abstract}
This Research aims to improve Improving Early Reading Ability by Using Flannel Board Media at Grup B TK Harapan Kita Alebo, Konawe Selatan". The subjects in this study were teachers and students consisting 16 people. This type of research is classroom action research carried out in two cycles. Data collection in this study uses the observation, interview and documentation methods. Based on the analysis of observational data on teacher teaching activities in the first cycle obtained an achievement percentage of $73,3 \%$, student learning activities obtained percentage achievement 69,28\%, while children's learning outcomes in the Improving Early Reading Ability by Using Flannel Board Media before the action is 37,5\%. children get BSB and BSH values then increase in cycle I by $62 \%$. In the second cycle, the percentage of achievement of teacher teaching activities increased to $92.37 \%$, the percentage of achievement of learning activities of students also increased to $92.3 \%$ and children's learning outcomes in the Improving Early Reading Ability by Using Flannel Board Media $87 \%$.
\end{abstract}

Keywords: Early Reading Ability, Flannel Board Media, Child.

\section{PENDAHULUAN}

Pendidikan merupakan salah satu upaya yang dapat dilakukan manusia untuk dapat mengembangkan kemampuan yang dimilikinya. Pendidikan anak usia dini (PAUD) adalah suatu upaya pembinaan yang ditujukan kepada anak sejak lahir sampai pada usia enam tahun yang dilakukan dengan memberikan ransangan pendidikan untuk membantu perkembangan jasmani dan rohani agar anak memiliki kesiapan dalam memasuki pendidikan lebih lanjut. Pendidikan anak usia dini penting dilaksanakan sebab anak usia 0-6 tahun berada pada masa 
peka yaitu masa dimana seluruh potensi anak dapat dikembangkan secara optimal baik dalam aspek fisik, bahasa, kongnitif, social emosional, maupun moral-agama (UU No. 20 Th 2003, pasal 1 ayat 14 tentang Sisdiknas).

Tentang standar pendidikan Anak Usia Dini menyebutkan bahwa pendidikan anak usia dini dilaksanakan melalui tiga jalur pendidikan yaitu pendidikan formal, nonformal dan informal. Menurut Ramli (2005:185) masa usia taman kanak- kanak (TK) merupakan manusia dengan rentang usia empat sampai enam tahun.

Bachri (2005: 4) mengelompokkan perkembangan bahasa menjadi empat yaitu; mendengar dan berbicara, serta membaca dan menulis. Aspek perkembangan bahasa sangatlah perlu dikembangkan karena dengan berbahasa anak dapat memahami kata dan kalimat serta memahami hubungan antara bahasa lisan dan tulisan menurut Suhartono (2005: 8), bahasa anak adalah bahasa yang dipakai oleh anak untuk menyampaikan keinginan, pikiran, harapan, permintaan, dan lain-lain untuk kepentingan pribadinya. Dhieni (2008: 1.12) bahasa adalah suatu modifikasi komunikasi yang meliputi sistem simbol khusus yang dipahami dan digunakan sekelompok individu untuk mengkomunikasikan berbagai ide dan informasi terhadap beberapa bahasa tertentu yang menggunakan 26 huruf $(\mathrm{a}-\mathrm{z})$ untuk menuliskan ribuan kata. Bahasa anak meliputi perkembangan fonologis (yakni mengenal dan memproduksi suara), perkembangan kosa kata, perkembangan semantik atau makna kata, perkembangan sintaksis atau penyusunan kalimat, dan perkembangan pragmatik atau penggunaan bahasa untuk keperluan komunikasi (sesuai dengan norma konvensi).

Perkembangan bahasa anak usia dini mengandung empat aspek keterampilan yaitu mendengar, berbicara, membaca, dan menulis. Kemampuan membaca permulaan dapat diketahui pada aktivitas visual melibatkan pemahaman simbol atau tulisan yang diucapkan dan menitik beratkan pada aspek ketepatan menyuarakan tulisan, lafal dan intonasi yang baik, kelancaran dan kejelasan suara sebagai bentuk pemerolehan makna maupun informasi. Kemampuan yang diperlukan dalam membaca diperoleh dari mengenal bentuk, mengenal perbedaan huruf, mengenal rangkaian (pola), dan mengenal perbedaan intonasi.
Morisson (2012: 265) menyatakan bahwa untuk menjadi pembaca yang mahir maka seorang anak memerlukan pengetahuan tentang nama huruf, kecepatan anak menyebutkan nama huruf, pemehaman fonemik (pemehaman hurufbunyi) dan pengalaman membaca dan dibacakan buku oleh orang lain.

Kemampuan membaca permulaan adalah kemampuan anak dalam mengidentifikasi berbagai bunyi huruf, memahami dan menyuarakan kata serta kalimat (Permendiknas No. 58 Tahun 2009 Tentang Pendidikan Anak Usia Dini).

Moeslichatoen (2004: 32-33) melalui kegiatan bermain anak dapat melatih kemampuan bahasanya dengan cara mendengarkan beraneka bunyi, mengucapkan suku kata atau kata, memperluas kosa, dan sebagainya. Anak mengekspresikan kata, dengan menggunakan permainan diharapkan mampu meningkatkan kemampuan membaca permulaan.

Anggraeni (2015: 51) mengatakan bahwa kemampuan membaca anak usia dini dapat dibagi atas empat tahap perkembangan sebagai berikut; a) tahap timbulnya kesadaran; b) tahap membaca gambar; c) tahap pengenalan bacaan; d) tahap membaca lancar.

Berdasarkan hasil observasi yang dilakukan peneliti dikelopok B TK Negeri Harapan Kita Alebo Kabupaten Konsel, menunjukan bahwa kemampuan membaca permulaan masih belum optimal. Hal ini disebabkan oleh media pembelajaran yang digunakan guru terbatas, yaitu dengan menggunakan media gambar yang ditempel di papan tulis dan menggunakan media yang telah dipajang di tembok yang hampir setiap hari anak melihat pajangan gambar tersebut, hal itu membuat anak tampak jenuh dalam belajar.

Hal ini dikarenakan pemberian stimulasi membaca pada anak kelompok B dengan cara memberi kalimat kompleks yang tidak disertai benda kongkrit maupun gambar yang mendukung. Dalam membaca anak belum jelas menyuarakan huruf, hal ini disebabkan karena dalam memahami perbedaan huruf masih terdapat kekeliruan.

Anak masih mengalami kebingungan membedakan huruf misalnya antara huruf " $b$ " dan "d", lalu "w" dan "m" hal ini dikarenakan huruf-huruf tersebut hampir sama bentuknya namun berbeda bunyinya 
Salah satu upaya yang dapat dilakukan guru untuk menstimulasi aspek perkembangan anak usia dini adalah dengan memanfaatkan media pembelajaran yang menarik yaitu melalui media papan flanel. Papan Flanel adalah suatu papan yang dilapisi kain flanel atau kain yang berbulu di mana adanya dilekatkan potongan gambar-gambar atau symbol-simbol yang lain. Contoh menempel gambar, dan huruf.

Media papan flanel sangat baik untuk diberikan pada anak dalam proses belajarnya, tetapi perlu dirancang suatu pembelajaran yang disesuaikan dengan minat anak dalam belajar khususnya dalam meningkatkan kemampuan membaca anak. Peneliti sengaja merancang suatu media yaitu media papan flanel yang terbuat dari kain flanel dan isinya memuat beberapa kegiatan seperti mengenalkan angka, bentuk dan warna pada anak melalui kegiatan yang menarik yang menjadikan media ini berbeda dengan media-media papan lainnya.

Media ini sengaja dibuat dari kain flanel dimana anak membutuhkan benda yang aman, tidak mudah rusak dan juga mudah dibersihkan. Selain itu media ini berisi gambar dan huruf abjad yang dapat merangsang beberapa aspek perkembangan merupakan bahasa anak seperti mendengar, berbicara, membaca, dan menulis.

\section{METODE}

Jenis penelitian ini adalah Penelitian Tindakan Kelas (PTK) atau Classroom Action Research yang dilaksanakan oleh guru didalam kelas. Action Research pada hakikatnya merupakan rangkaian "riset-riset tindakan", yang dilakukan secara siklus, dalam rangka memecahkan masalah, sampai masalah itu terpecahkan. Penelitian Tindakan Kelas (PTK) adalah penelitian yang dilakukan guru di dalam kelasnya sendiri melalui kegiatan refleksi diri, untuk memperbaiki kinerja sebagai guru, sehingga hasil belajar siswa menjadi meningkat.

Kemmis dalam Abdullah Sani dan Sudiran (2017: 2) penelitian tindakan kelas sebagai suatu bentuk penelaahan atau inkuri melalui refleksi diri yang dilakukan oleh peserta kegiatan pendidikan tertentu dalam situasi sosial untuk memperbaiki rasionalitas dan kebenaran.

Rapoport dalam Wiraatmadja (2010: 1112) mengartikan penelitian tindakan kelas untuk membantu seseorang dalam mengatasi secara praktis persoalan yang dihadapi dalam situasi darurat dan anak pada usia dini meliputi fisik- motorik, intelektual, moral, emosional, sosial, psikososial, kognitif dan bahasa.

Penelitian ini dilaksanakan di Kelompok B TK Negeri Harapan Kita Alebo di Jalan Kantor Balai Desa Alebo, Kecamatan Konda, Kabupaten Konawe Selatan. Penelitian Tindakan Kelas ini dilaksanakan pada Tahun ajaran 2018/2019. Waktu terhitung mulai bulan Januari sampai Februari. Subjek penelitian tindakan ini adalah 16 orang anak dengan 7 anak laki-laki dan 9 anak perempuan dengan usia 5-6 tahun.

Adapun faktor-faktor yang diamati peneliti dalam penelitian ini adalah Faktor guru, Faktor anak, dan Hasil belajar anak, Prosedur penelitian tindakan kelas ini dibagi dalam dua siklus yaitu sesuai dengan rencana seperti apa yang telah didesain dan faktor yang diselidiki.

Prosedur penelitian tindakan kelas ini dibagi dalam dua siklus dan masing-masing siklus teridiri empat kali pertemuan sesuai dengan rencana seperti apa yang telah didesain dan faktor yang diselidiki.

Iskandar (2012: 48) menjelaskan bahwa prosedur Penelitian Tindakan Kelas (PTK) dimulai dengan siklus pertama yang terdiri dari empat kegiatan, yaitu : perencanaan (planning), pelaksanaan (action). pengamatan (observing), refleksi (reflecting).

Rincian tahapan penelitian tindakan kelas adalah sebagai berikut:

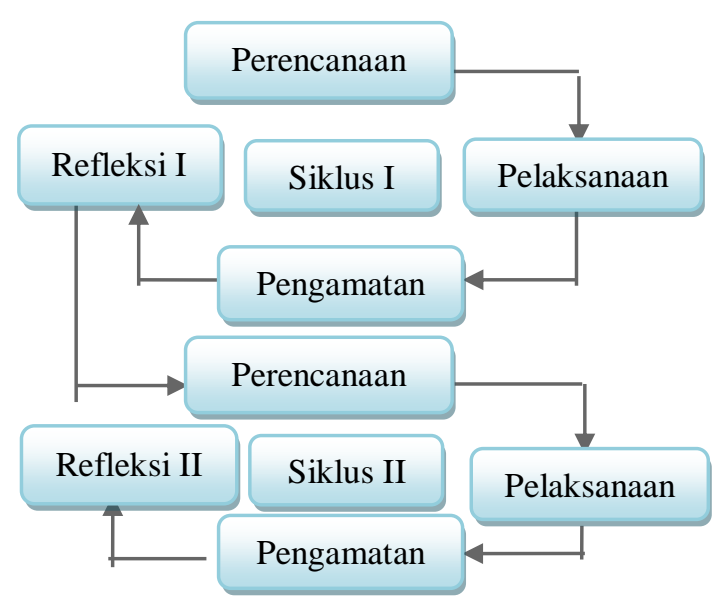

Gambar 1. Siklus Penelitian Tindakan

Teknik pengumpulan data merupakan bagian yang terpenting dalam suatu penelitian, bahkan merupakan suatu keharusan bagi seorang peneliti. Maka dalam penelitian tindakan kelas, peneliti peneliti menggunakan beberapa teknik pengumpulan data yaitu: observasi, wawancara, dan dokumentasi. 
Pengolahan data dalam penelitian ini dianalisis berdasarkan hasil penilaian kemampuan bahasa melalui media papan flanel. Dalam menganalisis data dan memberi penilaian pada setiap indikator kinerja, peneliti mengacu pada pedoman pemberian penilaian dalam satuan pendidikan di taman kanak-kanak, yaitu dengan penilaian secara kualitatif atau dengan memberikan nilai dalam bentuk simbol bintang, sebagai berikut: $*=$ Belum Berkembang $(\mathrm{BB})$, $* *=$ Mulai Berkembag $(\mathrm{MB}),{ }^{* * *}=$ Berkembang Sesuai Harapan $(\mathrm{BSH}), * * * *=$ Berkembang Sangat Baik (BSB) (Depdiknas, 2004: 26).

Tabel 1. Kategori Keberhasilan Klasikal

\begin{tabular}{rll}
\hline Nilai & Kategori & Simbol \\
$3,50-4,00$ & BSB & $* * * *$ \\
$2,50-3,49$ & BSH & $* * *$ \\
$1,50-2,49$ & MB & $* *$ \\
$0,01-1,49$ & BB & $*$
\end{tabular}

(Depdiknas, 2004: 26)

Untuk menentukan keberhasilan dan keefektifan penelitian ini, maka dirumuskan indikator kinerja yang digunakan sebagai acuan keberhasilan. Adapun indikator kinerja minimal $85 \%$ anak memperoleh nilai BSB dan BSH.

\section{HASIL DAN PEMBAHASAN}

Sebelum kegiatan penelitian ini dilaksanakan, peneliti terlebih dahulu melakukan pertemuan awal dengan Kepala TK Negeri Harapan Kita Alebo pada tanggal 27 september 2018. Pertemuan tersebut bermaksud untuk menyampaikan tujuan dari peneliti yaitu mengadakan penelitian di TK Negeri Harapan Kita Alebo. Selanjutnya, kepala TK mengarahkan peneliti untuk berdiskusi dengan guru kelompok B sekaligus sebagai observer/teman peneliti dalam pelaksanaan penelitian yang berkaitan dengan kegiatan yang akan dilakukan penliti yaitu tentang membaca permulaan melalui media papan flanel. Setelah itu, peneliti berbincang-bincang dengan guru kelompok B akhirnya mencapai kesepakatan untuk melakukan observasi awal pada tanggal 1 Oktober 2018 sekaligus meminta kesediaan guru kelompok B sebagai observer peneliti dalam melaksanakan penelitian.

Berdasarkan hasil observasi dan dilanjutkan dengan wawancara singkat dengan guru kelompok B di taman Kanak-Kanak tersebut, menunjukkan bahwa kemampuan membaca permulaan anak masih rendah yaitu berada pada taraf Mulai Berkembang (MB) dan Belum Berkembang (BB), atau dengan simbol nilai bintang $(* * *)$ dan $(*)$ sehingga perlu dikembangkan dan ditingkatkan lagi. Dari segi kurang berkembangnya kemampuan kognitif anak disebabkan oleh kurangnya media pembelajaran yang diterapkan dalam proses belajar anak, hal tersebut membuat minat belajar anak berkurang.

Berdasarkan permasalah yang dihadapi tersebut, maka peneliti berusaha merancang suatu kegiatan yang menarik dan menyenangkan bagi anak untuk meningkatkan kemampuan membaca permulaan anak melalui media papan flanel di kelompok B TK Negeri Harapan Kita Alebo sepakat untuk berkolaborasi dan menjadi mitra dalam kegiatan penelitian ini.

Pelaksanaan tindakan penelitian pada siklus I peneliti berkolaborasi dengan guru kelas B. Tugas peneliti adalah bertindak sebagai guru dimana peneliti melaksanakan kegiatan belajar mengajar sesuai dengan Rencana Pelaksanaan Pembelajaran Harian (RPPH) yang telah disusun oleh peneliti dan telah didiskusikan sebelumnya. Pertemuan pertama dilakukan pada hari Senin tanggal 11 Februari 2019 dengan tema pekerjaan dan sub tema pekerjaan penjahit.

Pelaksanaan tindakan siklus I pertemuan I dilaksanakan pada hari senin 11 Februari 2019, dari pukul 7.30-11.00 WITA di Kelompok B dengan jumlah sebanyak 16 orang anak didik. Adapun indikator yang akan dicapai oleh anak didik yaitu anak dapat membedakan antara dua gambar peralatan pekerjaan sesuai sub tema, anak dapat melafalkan bunyi huruf fokal sesuai sub tema, anak dapat mengurutkan gambar dengan huruf awal yang sama pekerjaan secara seriasi sesuai sub tema, dan anak dapat membaca gambar sesuai tema yang ada pada media papan flanel pada pelaksanaan tindakan ini, peneliti melaksanakan skenario pembelajaran pada RPPH I(tema/subtema: pekerjaan/penjahit).

Telah menjadi rutinitas di TK Negeri Harapan Kita Alebo setiap pagi anak didik terlebih dahulu membaca surah-surah, hadishadis, pembacaan asmaul husna. Setelah itu, guru mempersilahkan dan mengarahkan anak untuk cuci tangan dan makan bersama. 
Sebelum menjelaskan maksud dari kegiatan yang akan dilakukan, guru terlebih dahulu memperkenalkan media pembelajaran yang disediakan yaitu menggunakan media papan flanel dimana isi media tersebut terdiri dari beberapa kegiatan yang membahas tentang tema pada saat itu, yaitu tema pekerjaan penjahit dan dilanjutkan dengan menjelaskan semua indikator penilaian dalam penelitian. Sebelum membagikan gambar pada anak, guru juga menjelaskan aturan-aturan dalam menggunakan media. Kemudian anak diminta untuk mengerjakan tugas sesuai dengan yang dijelaskan, yaitu anak diminta untuk melafalkan antara bunyi huruf fokal gambar yang terdapat pada lembaran pertama pada media papan flanel, kegiatan kedua anak menyebutkan katakata yang mempunyai huruf awal yang sama melalui media papan flanel, kegiatan ke tiga anak dapat menghubungkan gambar dengan kata yang telah di baca pada media papan fkanel secara seriasi dan kegiatan selanjutnya anak membaca nama sendiri.

Pada kegiatan terakhir dimana guru meminta anak untuk duduk di tempat duduk masing-masing sebelum pulang guru membimbing anak untuk mengucapkan doa keselamatan dan doa sebelum pulang.

Pelaksanaan tindakan siklus I pertemuan II dilaksanakan pada hari selasa 12 Februari 2019, dari pukul 7.30-11.00 WITA di Kelompok B dengan jumlah sebanyak 16 orang anak didik. Adapun indikator yang akan dicapai oleh anak didik yaitu anak menghubungkan gambar dengan kata pekerjaan sesuai sub anak dapat mengurutkan gambar peralatan pekerjaan secara seriasi sesuai sub tema, dan anak dapat menyebutkan huruf awal yang sama sesuai tema pada gambar peralatan pekerjaan sesuai sub tema. pada pelaksanaan tindakan ini, peneliti melaksanakan skenario pembelajaran pada RPPH II (tema/subtema:pekerjaan/penjahit).

Telah menjadi rutinitas di TK Negeri Harapan Kita Alebo setiap pagi anak didik terlebih dahulu membaca surah-surah, hadis-hadis, pembacaan asmaul husna, guru mempersilahkan dan mengarahkan anak untuk cuci tangan dan makan bersama.

Sebelum menjelaskan maksud dari kegiatan yang akan dilakukan, guru terlebih dahulu memperkenalkan media pembelajaran yang disediakan yaitu menggunakan media papan flanel dimana isi media tersebut terdiri dari beberapa kegiatan yang membahas tentang tema pada saat itu, yaitu tema pekerjaan penjahit dan dilanjutkan dengan menjelaskan semua indicator penilaian dalam penelitian. Sebelum membagikan gambar pada anak, guru kembali menjelaskan aturan-aturan dalam menggunakan media. Kemudian anak diminta untuk mengerjakan tugas sesuai dengan yang dijelaskan, yaitu anak diminta untuk melagalkan huruf fokal, kegiatan kedua anak menghubungkan gambar dengan kata berdasarkan tema, kegiatan ke tiga anak mengurutkan gambar sesuai huruf awal yang sama secara seriasi ), dan kegiatan selanjutnya anak membaca nama sendiri.

Pada kegiatan terakhir dimana guru meminta anak untuk kembali duduk ditempat duduknya masing-masing, sebelum pulang guru membimbing anak untuk mengucapkan doa keselamatan dan doa sebelum pulang.

Pekerjaan berdasarkan warnanya sesuai sub tema, anak dapat mengurutkan gambar peralatan pekerjaan secara seriasi sesuai sub tema, dan anak dapat mencocokkan lambang bilangan dengan jumlah benda pada gambar peralatan pekerjaan sesuai sub tema. pada pelaksanaan tindakan ini, peneliti melaksanakan skenario pembelajaran pada RPPH II (tema/subtema: pekerjaan/penjahit).

Pelaksanaan tindakan siklus I pertemuan III dilaksanakan pada hari rabu 13 Februari 2019, dari pukul 7.30-11.00 WITA di Kelompok B dengan jumlah sebanyak 15 orang anak didik.

Adapun indikator yang akan dicapai oleh anak didik yaitu anak dapat membedakan antara dua gambar peralatan pekerjaan sesuai sub tema, anak dapat melafalkan bunyi huruf fokal sesuai sub tema, anak dapat mengurutkan gambar dengan huruf awal yang sama pekerjaan secara seriasi sesuai sub tema, dan anak dapat membaca gambar sesuai tema yang ada pada media papan flanel pada pelaksanaan tindakan ini, peneliti melaksanakan skenario pembelajaran pada RPPH I(tema/subtema: pekerjaan/penjahit).

Telah menjadi rutinitas di TK Negeri Harapan Kita Alebo setiap pagi anak didik terlebih dahulu membaca surah-surah, hadishadis, pembacaan asmaul husna. Setelah itu, guru mempersilahkan dan mengarahkan anak untuk cuci tangan dan makan bersama.

Sebelum menjelaskan maksud dari kegiatan yang akan dilakukan, guru terlebih dahulu memperkenalkan media pembelajaran yang disediakan yaitu menggunakan media papan flanel dimana isi media tersebut terdiri 
dari beberapa kegiatan yang membahas tentang tema pada saat itu, yaitu tema pekerjaan penjahit dan dilanjutkan dengan menjelaskan semua indikator penilaian dalam penelitian. Sebelum membagikan gambar pada anak, guru juga menjelaskan aturan-aturan dalam menggunakan media. Kemudian anak diminta untuk mengerjakan tugas sesuai dengan yang dijelaskan, yaitu anak diminta untuk melafalkan antara bunyi huruf fokal gambar yang terdapat pada lembaran pertama pada media papan flanel, kegiatan kedua anak menyebutkan katakata yang mempunyai huruf awal yang sama melalui media papan flanel, kegiatan ke tiga anak dapat menghubungkan gambar dengan kata yang telah di baca pada media papan fkanel secara seriasi dan kegiatan selanjutnya anak membaca nama sendiri.

Pada kegiatan terakhir dimana guru meminta anak untuk duduk di tempat duduk masing-masing sebelum pulang guru membimbing anak untuk mengucapkan doa keselamatan dan doa sebelum pulang.

Pelaksanaan tindakan siklus I pertemuan IV dilaksanakan pada hari kamis 14 Februari 2019, dari pukul 7.30-11.00 WITA di Kelompok B dengan jumlah sebanyak 16 orang anak didik. Adapun indikator indikator yang akan dicapai oleh anak didik yaitu anak dapat membedakan antara dua gambar peralatan pekerjaan sesuai sub tema, anak dapat melafalkan bunyi huruf fokal sesuai sub tema, anak dapat mengurutkan gambar dengan huruf awal yang sama pekerjaan secara seriasi sesuai sub tema, dan anak dapat membaca gambar sesuai tema yang ada pada media papan flanel pada pelaksanaan tindakan ini, peneliti melaksanakan skenario pembelajaran pada RPPH I(tema/subtema: pekerjaan/penjahit).

Telah menjadi rutinitas di TK Negeri Harapan Kita Alebo setiap pagi anak didik terlebih dahulu membaca surah-surah, hadishadis, pembacaan asmaul husna. Setelah itu, guru mempersilahkan dan mengarahkan anak untuk cuci tangan dan makan bersama.

Sebelum menjelaskan maksud dari kegiatan yang akan dilakukan, guru terlebih dahulu memperkenalkan media pembelajaran yang disediakan yaitu menggunakan media papan flanel dimana isi media tersebut terdiri dari beberapa kegiatan yang membahas tentang tema pada saat itu, yaitu tema pekerjaan penjahit dan dilanjutkan dengan menjelaskan semua indikator penilaian dalam penelitian. Sebelum membagikan gambar pada anak, guru juga menjelaskan aturan-aturan dalam menggunakan media. Kemudian anak diminta untuk mengerjakan tugas sesuai dengan yang dijelaskan, yaitu anak diminta untuk melafalkan antara bunyi huruf fokal gambar yang terdapat pada lembaran pertama pada media papan flanel, kegiatan kedua anak menyebutkan katakata yang mempunyai huruf awal yang sama melalui media papan flanel, kegiatan ke tiga anak dapat menghubungkan gambar dengan kata yang telah di baca pada media papan fkanel secara seriasi dan kegiatan selanjutnya anak membaca nama sendiri. membimbing anak untuk mengucapkan doa keselamatan dan doa sebelum pulang.

Hasil analisis observasi guru sesuai dengan lembar observasi sebanyak 15 aspek yang diamati harus dicapai oleh guru. Aspek yang harus dicapai oleh guru diantaranya: (1) Guru mengucapkan salam sebelum memulai pembelajaran; (2) Guru mengarahkan anak untuk berdo'a sebelum belajar; (3) Guru melakukan apresepsi yang berkaitan dengan tema/sub tema (4) Guru menyiapkan dan perkenalkan media papan flanel berisi huruf abjad; (5) Guru menjelaskan kegiatan yang akan dilakukan; (6) Guru meminta anak untuk memperhatikan kegiatan yang akan dilakukan; (7) Guru mengajukan pertanyaan kepada anak dengan tujuan untuk mengetahui sejauh mana pemahaman anak tentang pemebelajaran yang telah diberikan; (8) Guru untuk melafalkan bunyi huruf vocal yang ada dimedia papan flanel; (9) Guru meminta anak untuk menyebutkan kata-kata yang mempunyai huruf awal yang sama

Siklus I pertemuan I skor yang dicapai guru dari 15 aspek adalah \% (8 aspek yaitu pada point $1,5,6,8,7,9,10,11)$, kemudian pada pertemuan II skor yang dicapai guru adalah $60 \%$ (9 aspek yaitu pada point $1,4,5,6,8,9$, $10,11,12,13)$, selanjutnya pada pertemuan III skor yang dicapai guru adalah 66 (10 aspek yaitu pada point $1,4,5,6,8,9,10,11,12$, $13,14$,$) , dan pada pertemuan IV skor yang$ dicapai guru adalah $78.57 \%$ (11 aspek yaitu pada point $1,2,4,5,6,8,9,10,11,12,13)$. Lebih jelasnya dapat dilihat pada histogram berikut: 


\section{Gambar 1. Diagram Hasil Analisis Aktivitas Mengajar Guru Siklus I}

Analisis hasil observasi anak didik sesuai dengan lembar observasi pada siklus I sebanayak 13 aspek diamati diharapkan tercapai, diantanya: (1) Anak mempersiapkan diri untuk belajar; (2) anak menjawab salam; (3) Anak mengikuti intruksi guru untuk berdo'a sebelum belajar; (4) Anak memperhatikan guru saat memperkenalkan media pembelajaran; (5) Anak memperhatikan penjelasan guru tentang kegiatan pembelajaran yang akan dilakukan (6) Anak melafalkan bunyi huruf vocal yang ada di media papan flanel; (7) Anak menyebutkan kata-kata yang mempunyai huruf awal yang sama melalui media papan flanel sesuai yang diperintahkan oleh guru (8) Anak melakukan tanta jawab dengan guru mengenai kegiatan belajar yang telah dilakukan dari awal hingga akhir kegiatan belajar (9) Anak mendengarkan arahan guru untuk bernyanyi serta berdo'a sebelum pulang. Lebih jelasnya dapat dilihat pada histogram berikut:

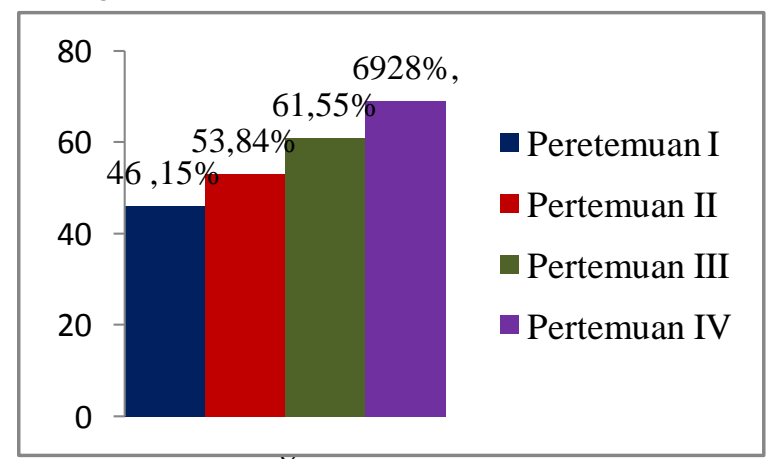

Gambar 1. Diagram Hasil Analisis Aktivitas Anak pada Siklus I

Siklus I pertemuan I skor yang dicapai anak didik dari 13 aspek adalah 46\% (6 aspek yaitu pada point $2,8,9,10,11,13$ ), kemudian pada pertemuan II skor yang dicapai anak didik adalah $46.15 \%$ (6 aspek yaitu pada point $1,2,5$,
$8,9,10,11)$, selanjutnya pada pertemuan III skor yang dicapai anak didik adalah $61 \%$ (7 aspek yaitu pada point $1,2,5,6,8,9,10,11$,), dan pada pertemuan IV skor yang dicapai anak didik adalah $69 \%$ (8 aspek yaitu pada point 1,2 , $5,6,7,8,9,10,11)$.

Tabel 1. Nilai Klasikal pada Siklus I

\begin{tabular}{lcc}
\hline \multicolumn{1}{c}{ Kategori } & $\begin{array}{c}\text { Jumlah } \\
\text { Anak }\end{array}$ & $\begin{array}{c}\text { Persentase } \\
(\%)\end{array}$ \\
$\begin{array}{l}\text { Berkembang } \\
\text { Sangat Baik }\end{array}$ & 4 & $25 \%$ \\
$\begin{array}{l}\text { Berkembang } \\
\text { Sesuai Harapan } \\
\text { Mulai }\end{array}$ & 6 & $37,5 \%$ \\
$\begin{array}{l}\text { Berkembang } \\
\text { Belum }\end{array}$ & 4 & $25 \%$ \\
$\begin{array}{l}\text { Berkembang } \\
\text { Jumlah }\end{array}$ & 2 & $12,5 \%$ \\
\hline
\end{tabular}

Berdasarkan hasil yang diperoleh pada Tabel 1. terlihat bahwa secara klasikal kegiatan meningkatkan kemampuan membaca permulaan melaui media papan flanel sebagian besar anak belum bisa melaksanakan kegiatan dengan baik yaitu $62 \%$ anak memperoleh nilai BSB dan BSH namun belum mencapai indikator kinerja yang ditetapkan yaitu $87 \%$ anak memperoleh nilai BSB dan BSH. Oleh karena itu, guru dan peneliti mendiskusikan kekurangan-kekurangan apa saja yang terdapat pada pelaksanaan tindakan siklus I untuk kemudian diperbaiki dan dilaksanakan pada siklus II.

Hasil refleksi dengan observer maka beberapa hal yang harus diperbaiki adalah guru masih kurang dalam menyampaikan tujuan pembelajaran, masih kurang dalam menyampaikan tujuan pembelajaran yang dilakukan hari ini, guru masih kurang mampu dalam menyampaikan kesimpulan pada saat setelah kegiatan pembelajaran sehingga kemampuan membaca permulaan anak belum optimal. Maka guru dan observer sepakat untuk dilanjutkan pada siklus II.

Pelaksanaan tindakan siklus II pertemuan I dilaksanakan pada hari selasa tanggal 18 Februari 2019, dari pukul 7.30-11.00 WITA di Kelompok B dengan jumlah sebanyak 16 orang anak didik. Adapun indikator yang akan dicapai oleh anak didik yaitu anak dapat membedakan antara dua gambar peralatan pekerjaan sesuai sub tema, anak dapat mengelompokkan gambar peralatan pekerjaan berdasarkan warnanya 
sesuai sub tema, anak dapat mengurutkan gambar peralatan pekerjaan secara seriasi sesuai sub tema, dan anak dapat menyebutkan kata dengan huruf awal yang sama pelaksanaan tindakan ini, peneliti melaksanakan skenario pembelajaran pada RPPH I (tema/subtema: pekerjaan/dokter).

Telah menjadi rutinitas di TK Negeri Harapan Kita Alebo setiap pagi anak didik terlebih dahulu membaca surah-surah, hadishadis, pembacaan asmaul husna. Setelah itu, guru mempersilahkan dan mengarahkan anak untuk cuci tangan dan makan bersama

Sebelum menjelaskan maksud dari kegiatan yang akan dilakukan, guru terlebih dahulu memperkenalkan media pembelajaran yang disediakan yaitu menggunakan media papan flanel dimana isi media tersebut terdiri dari beberapa kegiatan yang membahas tentang tema pada saat itu, yaitu tema pekerjaan dokter dan dilanjutkan dengan menjelaskan semua indikator penilaian dalam penelitian.

Pada saat guru membagikan kartu gambar pada anak, guru juga menjelaskan aturan-aturan dalam menggunakan buku pintar pada siklus II. Kemudian anak diminta untuk mengerjakan tugas sesuai dengan yang dijelaskan, yaitu anak diminta untuk menempel huruf sesuai nama gambar yang terdapat media buku papan flanel, kegiatan kedua anak menghubungkan gambar dengan kata gambar dokter, kegiatan ke tiga anak menempel kata dokter secara, dan kegiatan.

Pada kegiatan terakhir dimana guru menerapkan kegiatan tanya jawab untuk mengetahui tingkat pemahaman anak. Setelah itu anak diminta untuk mengembalikan media papan flanel, lalu anak kembali duduk ditempat duduknya masing-masing, sebelum pulang guru membimbing anak untuk mengucapkan doa keselamatan dan doa sebelum pulang.

Pelaksanaan tindakan siklus II pertemuan II dilaksanakan pada hari selasa tanggal 17 Februari 2019, dari pukul 7.30-11.00 WITA di Kelompok B dengan jumlah sebanyak 16 orang anak didik. Adapun indikator yang akan dicapai oleh anak didik yaitu anak dapat membedakan antara dua gambar peralatan pekerjaan sesuai sub tema, anak dapat mengelompokkan gambar peralatan pekerjaan berdasarkan warnanya sesuai sub tema, anak dapat mengurutkan gambar peralatan pekerjaan secara seriasi sesuai sub tema, dan anak dapat menyebutkan kata dengan huruf awal yang sama pelaksanaan skenario pembelajaran pada RPPH II (tema/subtema: pekerjaan/dokter).

Telah menjadi rutinitas di TK Negeri Harapan Kita Alebo setiap pagi anak didik terlebih dahulu membaca surah-surah, hadishadis, pembacaan asmaul husna. Setelah itu, guru mempersilahkan dan mengarahkan anak untuk cuci tangan dan makan bersama.

Sebelum menjelaskan maksud dari kegiatan yang akan dilakukan, guru terlebih dahulu memperkenalkan media pembelajaran yang disediakan yaitu menggunakan media papan flanel dimana isi media tersebut terdiri dari beberapa kegiatan yang membahas tentang tema pada saat itu, yaitu tema pekerjaan dokter dan dilanjutkan dengan menjelaskan semua indikator penilaian dalam penelitian.

Pada saat guru membagikan kartu gambar pada anak, guru juga menjelaskan aturan-aturan dalam menggunakan buku pintar pada siklus II. Kemudian anak diminta untuk mengerjakan tugas sesuai dengan yang dijelaskan, yaitu anak diminta untuk menempel huruf sesuai nama gambar yang terdapat media buku papan flanel, kegiatan kedua anak menghubungkan gambar dengan kata gambar dokter, kegiatan ke tiga anak menempel kata dokter secara, dan kegiatan.

Pada kegiatan terakhir dimana guru menerapkan kegiatan tanya jawab untuk mengetahui tingkat pemahaman anak. Setelah itu anak diminta untuk mengembalikan media papan flanel, lalu anak kembali duduk ditempat duduknya masing-masing, sebelum pulang guru membimbing anak untuk mengucapkan doa keselamatan dan doa sebelum pulang.

Pelaksanaan tindakan siklus II pertemuan III dilaksanakan pada hari kamis tanggal 20 Februari 2019, dari pukul 7.30-11.00 WITA di Kelompok B dengan jumlah sebanyak 16 orang anak didik. Adapun indikator yang akan dicapai oleh anak didik yaitu anak dapat membedakan antara dua gambar peralatan pekerjaan sesuai sub tema, anak dapat mengelompokkan gambar peralatan pekerjaan berdasarkan warnanya sesuai sub tema, anak dapat mengurutkan gambar peralatan pekerjaan secara seriasi sesuai sub tema, dan anak dapat menyebutkan kata dengan huruf awal yang sama pelaksanaan/skenario pembelajaran pada RPPH II (tema/subtema: pekerjaan/dokter).

Telah menjadi rutinitas di TK Negeri Harapan Kita Alebo setiap pagi anak didik terlebih dahulu membaca surah-surah, hadishadis, pembacaan asmaul husna. Setelah itu, 
guru mempersilahkan dan mengarahkan anak untuk cuci tangan dan makan bersama

Sebelum menjelaskan maksud dari kegiatan yang akan dilakukan, guru terlebih dahulu memperkenalkan media pembelajaran yang disediakan yaitu menggunakan media papan flanel dimana isi media tersebut terdiri dari beberapa kegiatan yang membahas tentang tema pada saat itu, yaitu tema pekerjaan dokter dan dilanjutkan dengan menjelaskan semua indikator penilaian dalam penelitian.

Pada saat guru membagikan kartu gambar pada anak, guru juga menjelaskan aturan-aturan dalam menggunakan media papan flanel pintar pada siklus II. Kemudian anak diminta untuk mengerjakan tugas sesuai dengan yang dijelaskan, yaitu anak diminta untuk menempel huruf sesuai nama gambar yang terdapat media buku papan flanel, kegiatan kedua anak menghubungkan gambar dengan kata gambar dokter, kegiatan ke tiga anak menempel kata dokter secara, dan kegiatan.

Pada kegiatan terakhir dimana guru menerapkan kegiatan tanya jawab untuk mengetahui tingkat pemahaman anak. Setelah itu anak diminta untuk mengembalikan media papan flanel, lalu anak kembali duduk ditempat duduknya masing-masing, sebelum pulang guru membimbing anak untuk mengucapkan doa keselamatan dan doa sebelum pulang.

Pelaksanaan tindakan siklus II pertemuan IV dilaksanakan pada hari senin tanggal 21 Maret 2019, dari pukul 7.30-11.00 WITA di Kelompok B dengan jumlah sebanyak 16 orang anak didik. Adapun indikator yang akan dicapai oleh anak didik yaitu anak dapat membedakan antara dua gambar peralatan pekerjaan sesuai sub tema, anak dapat mengelompokkan gambar peralatan pekerjaan berdasarkan warnanya sesuai sub tema, anak dapat mengurutkan gambar peralatan pekerjaan secara seriasi sesuai sub tema, dan anak dapat menyebutkan kata dengan huruf awal yang sama pelaksanaan/skenario pembelajaran pada RPPH II (tema/subtema: pekerjaan/dokter).

Telah menjadi rutinitas di TK Negeri Harapan Kita Alebo setiap pagi anak didik terlebih dahulu membaca surah-surah, hadishadis, pembacaan asmaul husna. Setelah itu, guru mempersilahkan dan mengarahkan anak untuk cuci tangan dan makan bersama

Sebelum menjelaskan maksud dari kegiatan yang akan dilakukan, guru terlebih dahulu memperkenalkan media pembelajaran yang disediakan yaitu menggunakan media papan flanel dimana isi media tersebut terdiri dari beberapa kegiatan yang membahas tentang tema pada saat itu, yaitu tema pekerjaan dokter dan dilanjutkan dengan menjelaskan semua indikator penilaian dalam penelitian.

Pada saat guru membagikan kartu gambar pada anak, guru juga menjelaskan aturan-aturan dalam menggunakan buku pintar pada siklus II. Kemudian anak diminta untuk mengerjakan tugas sesuai dengan yang dijelaskan, yaitu anak diminta untuk menempel huruf sesuai nama gambar yang terdapat media buku papan flanel, kegiatan kedua anak menghubungkan gambar dengan kata gambar dokter, kegiatan ke tiga anak menempel kata dokter secara, dan kegiatan.

Pada kegiatan terakhir dimana guru menerapkan kegiatan tanya jawab untuk mengetahui tingkat pemahaman anak. Setelah itu anak diminta untuk mengembalikan media papan flanel, lalu anak kembali duduk ditempat duduknya masing-masing, sebelum pulang guru membimbing anak untuk mengucapkan doa keselamatan dan doa sebelum pulang.

Selama proses pembelajaran berlangsung, guru sebagai observer mengamati jalannya pembelajaran dengan menggunakn lembar observasi untuk guru dan lembar observasi untuk anak. Kegiatan observasi dilakukan bersamaan dengan pelaksanaan tindakan untuk setiap pertemuan pada siklus II.

Hasil analisis observasi guru sesuai dengan lembar observasi sebanyak 15 aspek yang diamati harus dicapai oleh guru. Aspek yang harus dicapai oleh guru diantaranya: (1) Guru mengucapkan salam sebelum memulai pembelajaran; (2) Guru mengarahkan anak untuk berdo'a sebelum belajar; (3) Guru menyampaikan tujuan pembelajaran; (4) Guru melakukan apresiasi yang berkaitan dengan tema/sub tema (5) Guru menyiapkan dan memperkenalkan media papan flanel berisi huruf abjad; (6) Guru menjelaskan kegiatan yang akan dilakukan (7) Guru meminta anak untuk memperhatikan kegiatan yang akan dilakukan; (8) Guru mengajukan pertanyaan kepada anak dengan tujuan untuk mengetahui sejauh mana pemahaman anak tentang pembelajaran yang telah diberikan (9) Guru meminta anak untuk melafalkan bunyi huruf vocal yang ada dimedia papan flanel; (10) Guru meminta anak untuk menyebutkan kata-kata yang mempunyai huruf awal yang sama melalui media papan flanel; (11) Guru meminta anak untuk menghubungkan gambar dengan kata 
yang sudah dibaca sesuai tema (12) Guru meminta anak untuk membaca nama sendiri; (13) Guru melakukan tanya jawab mengenai kegiatan yang telah berlangsung dari awal hingga akhir kegiatan (14) Guru mengarahkan anak untuk bernyanyi serta berdo'a sebelum pulang.

Siklus II pertemuan I skor yang dicapai guru dari 15 aspek adalah 66\% (10 aspek yaitu pada point $1,4,5,6,8,9,10,11,12,13)$, kemudian pada pertemuan II skor yang dicapai guru adalah $73 \%$ (11 aspek yaitu pada point 1 , $3,4,5,6,8,9,10,11,12,13)$, selanjutnya pada pertemuan III skor yang dicapai guru adalah 86\% (13 apek yaitu pada point 1, 2, 3, 4, 5, 6, 8, $9,10,11,12,13,14)$, dan pada pertemuan IV skor yang dicapai guru adalah 92. 86\% (14 aspek yaitu pada point 1, 2,3, 4, 5, 6, 7, 8, 9, 10, $11,12,13,14)$.

Lebih jelasnya dapat dilihat pada histogram berikut:

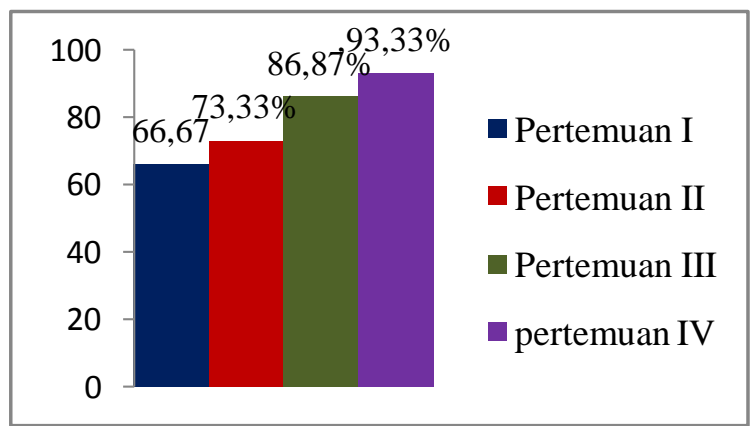

Gambar 3. Diagram Hasil Mengajar Guru Siklus II

Analisis hasil observasi anak didik sesuai dengan lembar observasi pada siklus II sebanayak 13 aspek diamati diharapkan tercapai, diantanya: (1) Anak mempersiapkan diri untuk belajar; (2) Anak menjawab salam;

(3) Anak memperhatikan guru saat penyampaian apresepsi (4) Anak menyebutkan kata-kata yang mempunyai huruf awal yang sama melalui media papan flanel sesuai yang diperintahkan oleh guru (5) Anak mengikuti intruksi guru untuk berdoa sebelum belajar; (6) Anak memperhatikan guru saat memperkenalkan media pembelajaran; (7) Anak memperhatikan penjelasan guru tentang kegiatan yang akan dilakukan; (8) Anak melafalkan bunyi huruf vocal yang ada di media papan flanel; (9) Anak dapat menghubungkan gambar dengan kata sesuai yang diperintahkan oleh guru; (10) Anak membaca nama sendiri (11) Anak melakukan tanya jawab dengan guru mengenai kegiatan belajar yang telah dilakukan dari awal hingga akhir kegiatan belajar (12) Anak mendengarkan arahan guru untuk bernyanyi serta brdoa sebelum pulang peralatan pekerjaan sesui sub tema. Siklus II pertemuan I skor yang dicapai anak didik dari 13 aspek adalah $76.92 \%$ (10 aspek yaitu pada point $1,2,4,5,8,9,10,11,12$, 13), kemudian pada pertemuan II skor yang dicapai anak didik adalah $84.62 \%$ (11 aspek yaitu pada point $1,2,4,5,7,8,9,10,11,12$, 13), selanjutnya pada pertemuan III skor yang dicapai anak didik adalah 92.3\% (12 apek yaitu pada point $1,2,4,5,6,78,9,10$, $11,12,13)$, dan pada pertemuan IV skor yang dicapai anak didik adalah 92.3\% (12 aspek yaitu pada point $1,2,4,5,6,78,9,10,11$, $12,13)$.

Lebih jelasnya dapat dilihat pada histogram berikut:

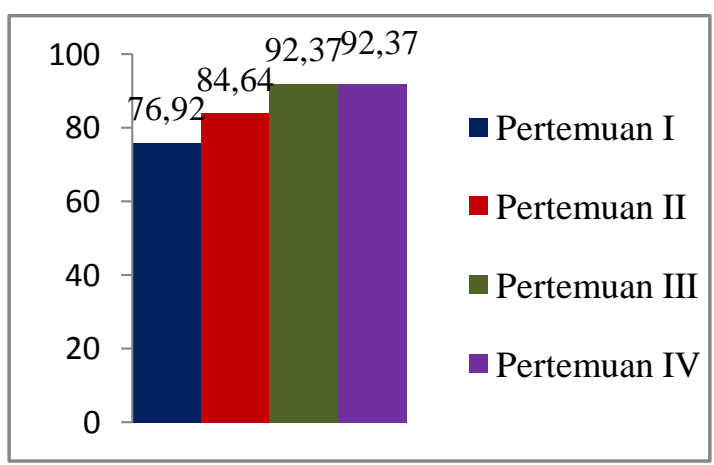

Gambar 4. Diagram Hasil Analisis Aktivitas Belajar Anak Didik Siklus II

Tabel 2. Nilai Klasikal pada Siklus II

\begin{tabular}{lcc}
\hline \multicolumn{1}{c}{ Kategori } & $\begin{array}{c}\text { Jumlah } \\
\text { Anak }\end{array}$ & $\begin{array}{c}\text { Presentase } \\
(\%)\end{array}$ \\
$\begin{array}{l}\text { Berkembang } \\
\begin{array}{l}\text { Sangat Baik (BSB) } \\
\text { Berkembang sesuai }\end{array}\end{array}$ & 5 & $31,25 \%$ \\
$\begin{array}{l}\text { Harapan (BSH) } \\
\text { Mulai Berkembang } \\
\text { (MB) }\end{array}$ & 9 & $56,25 \%$ \\
$\begin{array}{l}\text { Belum Berkembang } \\
\text { (BB) }\end{array}$ & 0 & $12,5 \%$ \\
Jumlah & 16 & $100 \%$ \\
\hline
\end{tabular}

Berdasarkan data hasil perolehan nilai anak didik yang ditampilkan pada Tabel 2, maka dapat disimpulkan bahwa secara klasikal perolehan nilai anak didik dalam kegiatan meningkatkan kemampuan membaca permulaan melalui media papan flanel di 
Kelompok B mengalami peningkatan, karena tingkat keberhasilan anak didik yaitu sebesar 87,5\% memperoleh nilai $\mathrm{BSH}$ dan BSB, dapat dikatakan bahwa sebagian besar anak didik dipandang telah mampu menyelesaikan tugastugas yang telah ditetapkan sesuai dengan indikator penilaian dalam penelitian ini khususnya dalam pelaksanaan tindakan siklus II. Adapun masih ada 2 anak yang belum mengalami peningkatan dalam hal ini perkembangan keterampilan sosial anak di sebabkan anak tersebut mengalami keterlambatan mental.

Selain itu dengan perolehan nilai sebesar $86,67 \%$ tersebut telah dicapai oleh 16 orang anak didik, sehingga secara umum program kegiatan atau rangkaian pelaksanaan pembelajaran dalam meningkatkan kemampuan membaca permulaan melalui media papan flanel telah terselesaikan dan mencapai indikator kinerja yaitu $85 \%$. Jika dilihat dari pemahaman anak didik mulai dari pelaksanaan siklus I sebesar $62,5 \%$ jika dibandingkan pada tahapan observasi awal/prasiklus penelitian yang hanya mencapai $37,5 \%$ dan pada tindakan siklus II mencapai persentase sebesar $87,5 \%$, menunjukkan hasil yang lebih baik dari sebelumnya, karena indikator kinerja yang ditetapkan telah tercapai yaitu minimal $85 \%$ maka guru dan observer sepakat bahwa penelitian ini dapat dihentikansampai pada siklus II.

\section{SIMPULAN DAN SARAN}

\section{Simpulan}

Berdasarkan observasi awal anak didik memperoleh nilai ketuntasan secara klasikal $37,5 \%$, dimana ada 2 orang anak didik yang mendapatkan nilai bintang (****) atau Berkembang Sangat Baik (BSB), dan 5 orang anak didik yang mendapatkan nilai bintang (***) atau Berkembang Sesuai Harapan (BSH). Pada siklus I mencapai 4 62,5\%, dimana ada orang anak didik yang mendapat nilai bintang $(* * * *)$ atau Berkembang Sangat Baik (BSB), dan ada 6 orang anak didik yang mendapat nilai bintang (***) atau Berkembang Sesuai Harapan (BSH). Selanjutnya pada siklus II dipeoleh $87,5 \%$ ketuntasan klasikal yaitu 5 orang anak didik yang mendapat nilai bintang (****) atau Berkembang Sangat Baik (BSB), dan 8 orang anak didik yang mendapat nilai bintang (***) atau Berkembang Sesuai Harapan (BSH).

Berdasarkan analisis data hasil observasi aktivitas mengajar guru pada siklus I sesuai dengan lembar observasi kegiatan mengajar guru sebanyak 15 aspek yang diamati dan 11 aspek yang telah dicapai guru, diperoleh $73,3 \%$. Sedangkan kegiatan belajar anak sesuai lembar observasi sebanyak 13 aspek dan 8 aspek yang telah dicapai anak, diperoleh 69,28.54\%. Pada siklus II aktivitas mengajar guru meningkat menjadi 93,3\%, sedangkan kegiatan belajar anak meningkat menjadi $92.3 \%$.

Dengan demikian dapat disimpulkan bahwa kemampuan membaca permulaan dapat di ditingkatkan melalui media papan flanel di kelompok B TK Negeri Harapan Kita Alebo Kabupaten Konawe Selatan.

\section{Saran}

Berdasarkan kesimpulan tersebut, maka peneliti menyarankan hal-hal sebagai berikut :

1. Bagi guru, sebaiknya dalam pelaksanaan proses pembelajaran hendaknya lebih mempertimbangkan media, metode, materi dan strategi yang tepat untuk anak didik, dan guru dituntut untuk lebih kratif dalam meningkatkan potensi yang dimiliki anak.

2. Bagi sekolah, diharapkan memperbanyak media pembelajaran untuk menunjang fasilitas pembelajaran bagi guru maupun anak didik.

3. Bagi peneliti, diharapkan agar hasil penelitian ini dapat dijadikan sebagai bahan rujukan dalam pelaksanaan penelitian, dapat menciptakan suasana menyenangkan dan kreatif agar anak lebih menarik lagi untuk belajar.

\section{DAFTAR PUSTAKA}

Abdul Sani, Ridwan., Sudiran. 2012. Penelitian Tindakan Kelas. Medan: Cita pustaka.

Anggraeni, Ria. 2015. Mengembangkan Kemampuan Kongnitif Anak melalui Media Papan Flanel di Taman Kanka-kanak Kasih Bunda Kampung Kalipapan

Kecamatan Negeri Agung

Kabupaten Way Kanan.

Lampung: Universitas Islam Negeri Raden Intan Lampung. ( skripsi). Diakses pada tanggal 11 Oktober 2018.

Bachri, Bachtiar. 2005. Pengembangan Kegiatan Bercerita di Taman KanakKanak (Teknik \& Proedurnya). Jakarta: Depdiknas RI. 
Dhieni, Nurbiana dkk. 2008. Metode Pengembangan Bahasa. Jakarta: Universitas Terbuka.

Depdiknas. 2003. Undang-undang Nomor 20 Tahun 2003 Tentang Sistem Pendidikan Nasional Pasal 1 ayat 14 tentang Sistem Pendidikan Nasional. Jakarta:Depdiknas

Depdiknas. 2004. Pedoman Penilaian di Taman Kanak-Kanak. Jakarta: Depdiknas.

Depdiknas. 2009. Permendikna No. 58. TentangStandar Tingkat Pencapaian Perkembangan Anak. Jakarta: Depdiknas.

Iskandar. 2012. Pendidikan Tindakan Kelas. Jakarta Selatan: Refrensi $\quad(\quad G P$ Press Grup).

Khadijah. 2016. Pengembangan Kongnitif Anak Usia Dini. Medan Perdana Mulya Sarana.

Moeslichatoen R. 2004. Metode Pengajaran di Taman Kanak- kanak. Jakarta: PT Rineka Cipta.

Morisson, George S. 2012. Dasar-Dasar Pendidikan Anak Usia Dini (PAUD).

Musfiroh, Tadkiroatun. 2005. Bercerita untuk Anak Usia Dini. Jakarta: Depdiknas.

Ramli, M. 2015. Pendampingan Perkembangan Anak Usia Dini. Jakarta:Depdiknas.

Suhartono. 2005. Pengembangan Keterampilan Bicara Anak Usia Dini. Jakarta: Depdiknas.

Wiriaatmadja, Rochiati. 2009. Metode Penelitian Tindakan Kelas. Bandung: PT. Remaja Rosdakarya. 